\title{
The Earned Income Tax Credit and Reported Self-Employment Income
}

\author{
Sara LaLumia*
}

April 4, 2009

\begin{abstract}
The Earned Income Tax Credit subsidizes earnings from both the wage sector and the self-employment sector. This paper uses tax return data to investigate how the EITC affects the reporting of self-employment income to the IRS. A difference-in-difference strategy is used, considering three expansions in the EITC and comparing changes across filers with and without children. The expansions are predicted to increase the reporting of self-employment income for those in the phase-in region of the EITC and to reduce the reporting of self-employment income for those in the phase-out region. Among the lowestincome filers, the 1994 EITC expansion is associated with a significant increase in the probability of reporting positive self-employment income, equal to 3.2 percentage points for unmarried filers and 4.1 percentage points for married filers.
\end{abstract}

The Earned Income Tax Credit (EITC) is widely recognized to have increased employment, particularly among single mothers with low levels of education. For purposes of calculating the credit, the tax code treats income earned through self-employment in nearly the same way as income earned through wage sector employment. This paper uses tax return data to investigate the effects of the EITC on the reporting of self-employment income to the IRS.

There are two reasons why the impact of the EITC on self-employment is of interest independent of its impact on wage sector employment. First, while overall self-employment rates have been declining in the long run, sociologists including Edin and Lein (1997) and Venkatesh (2006) have documented widespread informal self-employment among the poor. Edin and Lein interview 379 low-income single mothers, finding that $39 \%$ of welfare-reliant mothers and $28 \%$

${ }^{*}$ Department of Economics, Williams College, Williamstown MA 01267. Many thanks to Joel Slemrod, Jim Hines, Charlie Brown, Mary Corcoran, Therese McGuire, Samara Gunter and participants at the November 2006 National Tax Association meeting and February 2007 CSWEP workshop. All errors are my own. 
of wage-earning mothers supplement their income with "off-the-books" employment. This suggests the population most affected by EITC expansions may have relatively good access to informal self-employment opportunities. Second, self-employment is widely recognized to offer substantial opportunities for misreporting. Unlike wage employment, self-employment has no third party withholding tax or reporting information to the IRS. Data from the National Research Program of the IRS (2006) show that 57\% of self-employment income goes unreported. The discrepancy between reported and actual self-employment income makes it possible that reported self-employment will be particularly responsive to tax incentives. Slemrod (1990) suggests a hierarchy of responses to taxation in which "renaming" behaviors (such as reclassifying some previously unreported income as reported income) are more responsive to a tax change than are "real" changes in behavior (such as committing more time and effort to labor supply).

Figure 1 motivates the analysis of this paper. Using annual cross sections of tax return data, I plot the percentage of low-income returns reporting positive self-employment income, comparing the behavior of EITC recipients and non-recipients. ${ }^{1}$ Increases in EITC generosity are marked by vertical lines in the figure. The top panel shows information from returns of unmarried individuals. From 1984 to 1993, self-employment rates are similar for EITC recipients and non-recipients. After the most recent expansion, the reporting of positive self-employment income falls for non-recipients and rises dramatically for recipients. This is true even when I control for an important change in EITC eligibility. The EITC was first extended to filers without a child in 1994. Looking at taxpayers who claim both the EITC and a dependent exemption for a child living at home, a group that should be fairly stable over time, it is apparent that the reporting of self-employment income increases for EITC recipients relative to non-recipients. The bottom panel shows information from joint returns of married couples. For this group, EITC recipients are always more likely to report self-employment income than are

\footnotetext{
${ }^{1}$ Specifically, I use the publicly available 1984 - 1998 individual income tax return data provided by the Statistics of Income division of the IRS. I restrict the sample to returns with positive AGI, on which both real wage income and real AGI are below $\$ 30095$. A filing unit with earned income greater than this cutoff would be ineligible for the EITC in every year of my sample. Further details about the sample definition are in Section 3. My measure of self-employment income is net income reported on Schedule C, Profit or Loss from Business (Sole Proprietorship).
} 
non-recipients. The self-employment gap grows slightly following the most recent expansion.

In this paper I document the importance of self-employment income as a source of EITC payments. While only $13.5 \%$ of EITC recipients report self-employment income, approximately $70 \%$ of self-employed EITC recipients receive larger credits as a result of their self-employment income. On average, reported self-employment income increases a filer's EITC payment by about $\$ 650$. I also investigate whether three expansions in the EITC, effective in tax years 1987 , 1991, and 1994, are associated with changes in the reporting of self-employment income. I use a difference-in-difference strategy, comparing changes in reported self-employment across those with and without children. This strategy relies on the greater increases in EITC generosity for those with children than for those without children. I also use a more parametric specification that takes advantage of variation in the incentive to report self-employment income provided by state-level EITC programs. I find evidence that the decision to report self-employment income does in fact respond to the incentives created by the EITC. Those with the lowest levels of income are significantly more likely to report self-employment income after the 1994 expansion, consistent with the higher subsidy rate they faced. This pattern is evident for both married and unmarried filers, and survives a number of robustness checks. I find somewhat weaker evidence of a response to the high marginal tax rates generated by the phase-out region of the EITC. Unmarried filers with higher levels of income are less likely to report positive self-employment income after EITC expansions.

There is a substantial empirical literature investigating the labor supply effects of the EITC among single women, including Dickert et al. (1995), Eissa and Liebman (1996), Ellwood (2000), and Meyer and Rosenbaum (2001). The consensus from this literature is that the EITC has substantially increased the labor force participation rate of single women, with little effect on hours of work for those already employed. More recently, attention has turned to the effects on labor supply decisions of married individuals. If the primary earner's income is within the EITC phase-out range, the EITC reduces the net wage of the secondary earner and may therefore reduce her labor supply. Eissa and Hoynes (2004) show that the EITC expansions 
between 1984 and 1996 increased the participation rate of married men by only 0.2 percentage points, and reduced the participation rate of married women by 1 percentage point.

Only one previous paper has examined in detail the EITC and self-employment. Joulfaian and Rider (1996) use audit data from 1988 to investigate how the EITC affects tax evasion. They look separately at sole proprietors (the self-employed) and wage earners. They find no evidence that the negative marginal tax rates occurring in the phase-in range of the EITC induce over-reporting of income for either proprietors or wage earners. The positive and large marginal tax rates in the phase-out range do lead to understatement of income among proprietors, but not among wage earners. Even among proprietors, the effect is small. Joulfaian and Rider's simulations suggest that the income understatement of proprietors is about $9 \%$ higher due to the EITC. Unlike Joulfaian and Rider, I consider whether the EITC affects the decision to report self-employment income rather than treating self-employment status as exogenous. I use more recent data, because EITC expansions have generated benefit amounts much larger than 1988 levels. The use of unaudited tax return data means that I am unable to draw conclusions about compliance.

Although I focus particularly on the EITC, this paper is related to the broader question of how taxes affect self-employment. In the theoretical literature on this question, wage employment and self-employment differ in terms of risk and opportunity for tax evasion. Pestieau and Possen (1991) consider individuals choosing between riskless work in the wage sector and risky entrepreneurship, where tax evasion is possible only for entrepreneurs. In their model an increase in the tax rate has an ambiguous effect on both the fraction of individuals who choose entrepreneurship and the fraction of entrepreneurs who choose to evade. Kesselman (1989) develops a general equilibrium model with a fully compliant "above-ground" sector and a fully noncompliant "below-ground" sector. Under certain conditions, including a penalty for evasion that does not change with the tax rate, he shows that an increase in the tax rate can shift workers into the noncompliant sector. Domar and Musgrave (1944) show that a tax system in which losses can be used to reduce taxable income makes a risky investment relatively more at- 
tractive, by shifting some risk to the government. Many authors have applied this result to the self-employment decision, arguing that a more progressive tax system can shift workers into the relatively risky self-employment sector. On the other hand, Gentry and Hubbard (2000) show that when loss offsets are imperfect, a more progressive system can discourage self-employment. In short, there is disagreement in the theoretical literature about how a change in the tax rate will affect participation in self-employment.

The empirical literature investigating the relationship between tax rates and self-employment activity, summarized by Schuetze and Bruce (2004), has generated a wide range of estimates. The earliest work in this area, such as the time series evidence of Long (1982) and Blau (1987) and cross-sectional evidence of Moore (1983), indicated a positive relationship between federal marginal tax rates and the level of self-employment participation. Subsequent cross-sectional studies that have addressed the endogeneity of an individual's tax rate have weakened this early consensus. Bruce $(2000,2002)$ relies on exogenous changes in the payroll tax treatment of self-employment income relative to wage income. He finds that higher relative tax rates on self-employment income are associated with a higher probability of entry into self-employment and a lower probability of exit from self-employment. Using the same source of tax variation, but tax return data rather than survey data, Gurley-Calvez and Bruce (2008) find the opposite pattern; higher relative tax rates on self-employment income are associated with shorter duration of self-employment spells. Moore (2004) relies on the 1986 and 1993 tax reforms. Neither reform is shown to have a consistently significant effect on participation in self-employment. To the best of my knowledge, my paper is the first to take advantage of EITC-related exogenous tax variation to estimate the relationship between marginal tax rates and self-employment activity. $^{2}$

\footnotetext{
${ }^{2}$ As mentioned above, Joulfaian and Rider (1996) made use of the 1986 EITC expansion to identify the effects of marginal tax rates on compliance. Cullen and Gordon (2006) estimate the effects of various potential tax reforms, including elimination of the EITC, on risk-taking. They define risk-taking as reporting self-employment losses greater than $10 \%$ of wage and salary income, reasoning that profits can arise even from low-risk activities, but that losses are indicative of having undertaken a risky project. In simulations with 2005 tax law as the baseline, they show that the overall effect of the EITC is to discourage risk-taking.
} 


\section{Background on the EITC}

Administrative details about the EITC are described by the House Ways and Means Committee in the annual Green Book publication. Many details of the credit are well-known to economists, and Hotz and Scholz (2003) provide a thorough summary of research on who takes up the EITC, how their behaviors have responded to its incentives, and the degree to which they are complying with the tax law. Here I describe the elements of the EITC most relevant to my analysis of reported self-employment income.

The EITC is a refundable credit, with its amount determined by a taxpayer's earned income. Earned income includes wage and salary payments and net income from self-employment. ${ }^{3}$ If earned income falls within the phase-in region, the credit amount is equal to the subsidy rate multiplied by earnings. Over the years I analyze here, the subsidy rate has ranged from a low of $7.65 \%$ (for childless claimants) to a high of $40 \%$ (for claimants with two or more children). The maximum credit is equal to the subsidy rate multiplied by the income cutoff that separates the phase-in from the plateau region. For filers with children, this cutoff has ranged in nominal dollars from $\$ 5000$ in 1984 to $\$ 9390$ in 1998 . As earnings increase across the plateau region, the credit is constant at the maximum amount. Once earnings rise above the plateau cutoff, the credit is reduced at the phase-out rate. The beginning of the phase-out range has varied from $\$ 6000$ in 1984 to $\$ 12260$ in 1998 , and the end of the phase-out range from $\$ 10000$ in 1984 to $\$ 30095$ in 1998 .

Although the EITC is generally calculated as a function of earned income, the law does contain provisions to prevent those with low earnings and large amounts of unearned income from receiving the credit. Technically, a taxpayer is eligible for the smaller of two credit amounts. Prior to 1996, these two amounts were the credit corresponding to earned income and the credit corresponding to adjusted gross income (AGI), a broader income measure. Beginning in 1996, modified AGI replaced AGI in this calculation. Modified AGI is roughly AGI exclusive

\footnotetext{
${ }^{3}$ It also includes nontaxable earned income, such as housing and subsistence allowances from the military and voluntary salary deferrals contributed to certain retirement plans.
} 
of losses from sales of capital assets and exclusive of some percentage (50\% in 1996 and 1997, $75 \%$ beginning in 1998) of losses from self-employment. This reduces the possibility that an individual with wage earnings above the level subsidized by the EITC can use self-employment losses to become eligible for the credit. $^{4}$

The structure of the EITC generates different incentives for reporting self-employment income in the phase-in, plateau, and phase-out regions. The substitution effect of the credit on self-employment is analogous to the substitution effect on labor supply. In the phase-in region of the credit the payoff to work (either wage employment or self-employment) is higher. This should lead to increases in both actual and reported self-employment income. There is no substitution effect for those in the plateau region. An additional dollar of earnings does not change the credit received, and thus the return to self-employment is unchanged. The substitution effect discourages the earning and reporting of self-employment income for those in the phase-out region. The return to self-employment is lowered because each additional dollar of earnings reduces the credit received. For anyone initially earning some amount within the EITC range, disposable income will be higher with the credit than without. The income effect on actual self-employment income will be negative as long as leisure is a normal good. The income effect on reported self-employment income depends on relative risk aversion, as shown in the tax evasion models of Allingham and Sandmo (1972) and Yitzhaki (1974). In the realistic case where taxpayers have decreasing risk aversion, higher incomes are associated with greater evasion, or equivalently with reductions in reported self-employment income. Considering the combined substitution and income effects, the net effect should be an increase in reported selfemployment among those initially not working at all, an ambiguous effect for those initially in the phase-in region (but an increase if the substitution effect dominates), and a decrease in reported self-employment for those initially in either the plateau or phase-out region.

The credit has always been designed to give the greatest benefit to those with children.

\footnotetext{
${ }^{4}$ In my sample, I look for cases in which earned income exclusive of self-employment is greater than the EITC cutoff while earned income including self-employment losses is below the EITC cutoff. Such cases are rare, representing $0.36 \%$ of EITC recipients in the 1984-1995 period, $0.17 \%$ of EITC recipients in 1996 and 1997 , and $0.08 \%$ of EITC recipients in 1998 .
} 
Prior to 1994 the credit was only available to taxpayers with "qualifying children," children who meet relationship, residency, and age tests. A qualifying child must be a taxpayer's own child, grandchild, step child, or foster child. The child must live with the taxpayer for more than half of the year, and must be under age 19 (24 if a full-time student) or permanently disabled. If a child satisfies these tests for more than one taxpayer, only the taxpayer with the higher AGI can claim the child.

Filers with self-employment income use the tax return to report both their individual income tax liability and their Social Security tax liability. The Social Security tax is also known as the self-employment tax for self-employed individuals and the payroll tax for employees. ${ }^{5}$ For wage earners, Social Security tax is computed and withheld by employers. The law distinguishes between the employee's and employer's share of this tax, although standard tax incidence analysis suggests that this distinction has no real effects. Reporting an additional dollar of self-employment income can lower a filer's income tax liability (if he is in the phase-in region of the EITC) but always increases his Social Security tax liability, as long as net self-employment income exceeds $\$ 400 .{ }^{6}$ Since 1984 , the self-employment tax rate has been equal to the sum of the employee's and employer's payroll tax rates. Beginning in 1990, a self-employed taxpayer receives a deduction equal to half of the self-employment tax paid. Whether the Social Security tax is more or less onerous for the self-employed depends on the incidence of the employee and employer shares of the payroll tax. The standard assumption used by the Congressional Budget Office (2003) in performing distributional analysis of tax changes is that both shares are born by employees. Importantly for my empirical strategy, the Social Security tax is identical for those with and without children.

An individual contemplating reporting her self-employment income may face conflicting

\footnotetext{
${ }^{5}$ The tax an individual pays is offset somewhat by the corresponding increase in Social Security benefits. Feldstein and Samwick (1992) show that this offset varies with a taxpayer's age, sex, marital status, and income.

${ }^{6}$ No Social Security tax is owed on self-employment income below $\$ 400$. Once self-employment income exceeds $\$ 400$ tax is owed on the entire amount of income. There is some evidence of bunching just below the $\$ 400$ cutoff. I pool data from all years of my sample to sort self-employed taxpayers into bins based on net self-employment income. Approximately 1.8\% report net self-employment income of $\$ 351$ to $\$ 400$. This exceeds the share of returns in any other $\$ 50$ bin up to $\$ 1000$. Other bins contain between $0.6 \%$ and $1.0 \%$ of self-employed filers.
} 
incentives in the tax and welfare systems. Reporting the income on her tax return will increase her EITC if she is in the phase-in region, but reporting it to the welfare agency may reduce her benefits. Throughout this paper, I ignore any potential effect of self-employment income reported to the IRS on welfare benefits. ${ }^{7}$ One justification for doing so is that a large majority of EITC recipients do not receive welfare. Matching CPS data to 1990 tax return data, Liebman (2000) reports that only $16 \%$ of eligible EITC claimants and $3 \%$ of ineligible claimants received welfare. Hill et al. (1999) match state administrative data with tax return data from 1993 and 1994 to estimate EITC participation among welfare recipients, using a sample of AFDC (Aid to Families with Dependent Children) recipients from California. They estimate that $21 \%$ to $40 \%$ of single parent households on or recently on welfare are eligible for the EITC, and only about half of the eligible actually claimed the credit. The potential for misreporting provides a second justification for ignoring interactions between income reported to the IRS and benefits received from welfare. The amount of income reported to the IRS does not necessarily match the amount of income reported to a welfare agency. Hill et al. compare two sources of information on the earnings of welfare recipients, total earnings reported by individuals to welfare agencies and wages reported by employers to the state unemployment office. They find that $55 \%$ to $69 \%$ of single parent AFDC households with positive income, as shown in the state unemployment insurance database, underreport income to county welfare authorities. If easily-verified wage earnings are frequently misreported, it is reasonable to assume that selfreported self-employment earnings are misreported as well. An individual's welfare benefits will be unaffected by changes in self-employment income if the welfare agency is unaware of the self-employment income.

In addition to the federal EITC, several states offer similar tax credits conditional on earned income. Rhode Island became the first state to do so in 1986, introducing a non-refundable state EITC equal to $25 \%$ of a filer's federal EITC. As of 1998, ten states had such programs. ${ }^{8}$

\footnotetext{
${ }^{7}$ Since 1991, EITC payments themselves are not classified as income for purposes of calculating benefits from welfare, Medicaid, food stamps, and other means-tested programs.

${ }^{8}$ These states are Iowa, Kansas, Maryland, Massachusetts, Minnesota, New York, Oregon, Rhode Island, Vermont, and Wisconsin.
} 
These programs essentially exaggerate the marginal tax rates facing low income individuals, increasing the subsidy rate in the phase-in region and increasing the effective tax rate in the phase-out region. In some cases the additional state-level incentive is small. For example, Iowa's state EITC is only $6.5 \%$ of the federal EITC. The most generous state EITC program is Wisconsin's, with a state credit equal to $43 \%$ of the federal credit for filers with two or more children.

\section{Empirical Strategy}

My empirical strategy relies on exogenous variation in the payoff to reporting self-employment income that comes from three statutory expansions of the EITC. These expansions were passed in 1986, 1990, and 1993 and were first effective in tax years 1987, 1991, and 1994. I use data for years 1984 to 1998 and divide these years into four periods. The first, years 1984 to 1986, corresponds to low EITC benefits. The maximum phase-in rate was $11 \%$. The credit was expanded in 1986. In the second period I consider, 1987 to 1990, the phase-in rate was $14 \%$. The third period, years 1991 to 1993, reflects expansions passed by Congress in 1990 and then gradually phased in. By 1993, the phase-in rate was $18.5 \%$ for those with one child and $19.5 \%$ for those with two or more children. The fourth period consists of the five years after the most recent EITC expansion, years 1994 to 1998. In this time period the maximum phase-in rate was $34 \%$ for those with one child, $40 \%$ for those with multiple children, and $7.65 \%$ for those with no children. Additional information about the size of the credit in each time period is shown in Table 1.

Each EITC expansion changed the tax implications of reporting self-employment income, and changed these tax implications differently for those with and without children. I have used the NBER's tax calculator, TAXSIM, to compute how a filer's tax liability would change if she reported $\$ 500$ of (real) self-employment income, starting at various levels of wage income. ${ }^{9}$

\footnotetext{
${ }^{9}$ For details on the tax calculator, see Feenberg and Coutts (1993). TAXSIM does not distinguish between wage and self-employment income, so the actual procedure used in these calculations involved increasing wage
} 
Reporting self-employment income lowers tax liability (equivalently, increases the refundable credit amount) for those in the phase-in region and increases tax liability for those in the phase-out region. Each successive expansion of the EITC has magnified these effects.

Using the TAXSIM-calculated change in tax liability from reporting $\$ 500$ of self-employment income, in Figure 2 I plot the difference between this value for an unmarried filer with a dependent child and for an unmarried filer with no dependents. ${ }^{10}$ Wage and salary income exclusive of self-employment is graphed along the horizontal axis. The difference between filers with and without children in the payoff to reporting self-employment income is graphed along the vertical axis. Negative dollar amounts indicate reductions in tax liability. I consider four years, one in each of the four periods used in my difference-in-difference analysis. All dollar amounts are in real 1998 dollars. The vertical lines at real wage incomes of $\$ 9000$ and $\$ 14000$ represent the points at which I divide my sample into different groups for the empirical analysis. The differences shown in Figure 2 motivate my empirical strategy. At the lowest incomes, the tax implications of reporting self-employment income are always more favorable for those with children than for childless filers, and the advantage enjoyed by filers with children grows over time. For example, by reporting $\$ 500$ of self-employment income a 1985 filer with $\$ 3000$ in wage income and one dependent will reduce his tax liability by $\$ 55$ more than an otherwise identical filer with no dependents. In 1996, the filer with one dependent will lower his liability by $\$ 132$ more than an otherwise identical childless filer. At real incomes of $\$ 14000$ and higher, the situation is reversed. Reporting self-employment income is more costly for filers with children, and grows relatively more costly with each EITC expansion. ${ }^{11}$

I begin with a standard difference-in-difference framework, comparing changes in self-employment rates among the treatment group (those with children) to changes among the control group and salary income by the real equivalent of $\$ 500$.

${ }^{10} \mathrm{I}$ assume that an unmarried filer with a dependent child uses head of household filing status and that an unmarried filer with no dependents uses single filing status.

${ }^{11} \mathrm{~A}$ similar figure for those who are married and filing jointly is available upon request. It shows the same pattern of an increasing incentive for the lowest-income filers with children to report self-employment income, and an increasing disincentive for higher-income filers with children to report self-employment income. 
(those without children). I estimate probit equations of the following form:

$$
S E=\alpha_{0}+\alpha_{1} \text { Kids }+\beta \text { Period }+\delta(\text { Kids } \cdot \text { Period })+\gamma X+\epsilon
$$

The dependent variable is a dummy equal to 1 if a return reports positive self-employment income. The variable Kids is a measure of having any EITC qualifying children. The coefficient on this term represents the time-invariant difference in reported self-employment between those with and without children. The vector Period includes indicators for observations in the second, third, and fourth time periods, and Kids.Period includes the interaction of the time period dummies with the Kids variable. The coefficients on the period dummies represent the common change in self-employment experienced by those with and without children. The coefficient on the interaction terms represents the differential change in self-employment among those with children.

In the above equation, the vector $X$ includes state-level variables that are likely to affect self-employment decisions. The first of these is the state-level annual unemployment rate. As described by Parker (2004), the unemployment rate could affect self-employment rates either positively or negatively. If individuals are pushed into self-employment upon losing a wagesector job, the coefficient on state unemployment rate will be positive. On the other hand, the "pull" hypothesis is that a strong economy increases the likelihood of a new business succeeding, causing self-employment to look more attractive when the unemployment rate is low. In addition to EITC expansions, a number of other policy reforms of the late 1980s and 1990s changed the work incentives of single mothers relative to single childless women. Meyer and Rosenbaum (2001) show that EITC expansions and other tax changes explain $62 \%$ of the increase in single mothers' employment between 1984 and 1996, welfare waivers explain about $15 \%$, changes in maximum welfare benefit levels account for between 10 and 16\%, and Medicaid expansions explain a negligible part. It is possible that these other policy changes also affect participation in self-employment. Prior to the federal welfare reform of 1996, several states were 
granted waivers to implement welfare policies that differed from the standard federal AFDC program. In particular, many waivers allowed states to provide stronger work incentives for welfare recipients. I include in $X$ a variable measuring whether a state had a pre-1996 waiver that included a work requirement provision. ${ }^{12}$ I expect the coefficient on this variable to be negative, given that self-employment generally did not satisfy these work requirements. After the 1996 reform, states had even greater flexibility in designing their welfare programs, now known as Temporary Aid to Needy Families (TANF), and some states began to count selfemployment as an acceptable type of work activity. I include in $X$ a variable equal to 1 for post-reform observations from states and years in which self-employment was an acceptable work activity for TANF purposes. ${ }^{13}$ I expect the coefficient on this variable to be positive.

I estimate the above equation separately for those with real wage income under $\$ 9000$, between $\$ 9000$ and $\$ 14000$, and between $\$ 14000$ and $\$ 30095$. These categories correspond roughly to the three regions of the EITC. ${ }^{14}$ I expect that EITC expansions will increase reported selfemployment income in the lowest-income group and reduce reported self-employment income in the highest-income group. I estimate separate regressions for married and unmarried filers. Although the EITC provisions themselves do not distinguish between married and unmarried filers, the literature on the EITC's labor supply effects has tended to study married and unmarried filers separately. That literature suggests that unmarried filers have been much more responsive to the EITC.

Using the presence of children to define treatment and control groups assumes that, absent the EITC expansions, the self-employment rates of filers with and without children would have

\footnotetext{
${ }^{12}$ Details on state welfare waivers are provided in GAO (1997). I classify a state as having a work requirement if quitting a job, turning down a job offer, or failing to participate in work or work-readiness activities triggers a reduction or loss of benefits. The GAO reports the year and month of a waiver's approval rather than the date of its implementation. To account for lag time in implementation, I code a state as having a work requirement if an approved plan had been in place for more than six months of the year.

${ }^{13}$ Data on whether self-employment satisfies a state activity requirement come from the Urban Institute's Welfare Rules Database.

${ }^{14}$ The match between constant real dollar cutoffs and EITC regions is not exact because the real values of the cutoffs between EITC regions varied over time. In real 1998 dollars, the end of the phase-in region for a filer with one qualifying child has ranged from $\$ 6630$ to $\$ 8758$. The end of the plateau region has ranged from $\$ 9420$ to $\$ 13786$ and the end of the phase-out region has ranged from $\$ 15700$ to $\$ 26473$.
} 
evolved similarly. Some indirect evidence in support of this assumption comes from Fairlie and Meyer (2000). In their decomposition of changes in the black-white self-employment gap from 1940 to 1990, they find that changes in family structure (marital status and the presence of children) have very little explanatory power. My identification strategy further assumes that fertility decisions are exogenous to the EITC. This assumption is supported by two empirical papers. Baughman and Dickert-Conlin (2003) use variation in state EITC programs between 1990 and 1999 to investigate the effect of the EITC on first births. Among nonwhites, greater EITC benefits are associated with significantly higher birth rates, but the magnitude of the effect is small. The implied elasticities of birth rates are only 0.02 for unmarried nonwhite women and 0.06 for married nonwhite women. Baughman and Dickert-Conlin (forthcoming) expand this analysis to higher order births. They find no effect of EITC benefit levels on nonwhite births, and very small reductions in higher order birth rates among whites.

In addition to the difference-in-difference approach, I estimate a specification that takes advantage of additional variation provided by state-level EITC programs and by different rules for filers with more than one child. Here, I restrict my sample to filers with children. I regress the dummy for reporting positive self-employment income on the phase-in rate, a linear time trend, the state unemployment rate, a dummy for having a welfare waiver with a work requirement prior to 1996, and a dummy for counting self-employment as a work-related activity after 1996. I do this separately for married and for unmarried filers, for each of three income categories. An increase in the phase-in rate increases the return to reporting self-employment income. I expect the coefficient on the phase-in rate to be positive. As the phase-in rate is most relevant to those in the phase-in region, I expect results to be strongest for those in the lowest-income category.

Reported self-employment income can take on positive or negative values. I focus on only one of these, positive income, because naturally positive and negative income amounts affect tax liability in opposite ways. The structure of the EITC will theoretically discourage the reporting of negative income in the phase-in region (if the substitution effect dominates) and encourage 
it in the phase-out region. Empirically, the share of low income returns reporting negative selfemployment income is much smaller than the share reporting positive self-employment income.

\section{Data: Statistics of Income}

I use the annual cross sections of tax return data released by the Statistics of Income (SOI) division of the IRS. The SOI dataset is the best source of information on the types and amounts of income reported by taxpayers to the IRS. It is a nationally representative stratified sample of unaudited federal income tax returns, with some information removed or "blurred" to protect taxpayer confidentiality. ${ }^{15}$ Each year of data includes close to 100,000 records, with oversampling of high-income returns. Each cross section is drawn from all returns filed during a particular period, including late returns being filed for earlier tax years. Because of the blurring process, no record contains the full content of any actual return, and a given record may contain data from more than one actual return. Although the SOI dataset includes extremely detailed income information, it lacks even basic demographic information. ${ }^{16}$ I supplement the tax return data with data on state-level unemployment rates from the Bureau of Labor Statistics, data on state welfare waivers from the Goverment Accounting Office and from the Urban Institute, and parameters for state-level EITC programs from various state websites.

I impose a number of sample restrictions in order to focus on filers most likely to be affected by the EITC. Recall that a filer receives the smaller of the credit amount based on earnings and on (modified) AGI. Thus I restrict my sample to returns with real AGI between $\$ 1$ and $\$ 30095$ and with wage income not exceeding $\$ 30095$, the maximum amount a filer could earn and still qualify for the credit in 1998. By choosing upper income bounds expressed in constant real dollars, I ensure that my sample is not mechanically growing richer over time, but I include

\footnotetext{
${ }^{15}$ Certain income amounts are blurred in the following way. Records from each state are sorted by amount of the item to be blurred, the amount from each three adjacent returns is averaged, and this average replaces the original amount reported.

${ }^{16}$ Because I do not know the gender of the tax filer, I am unable to look separately at the responses of unmarried men and women.
} 
many returns that are ineligible for the EITC in the earlier years. I drop all late returns. ${ }^{17}$ I drop returns with a filing status of married filing separately because these filers are ineligible for the EITC. ${ }^{18}$ Finally, because I include state-specific covariates in my regressions, I drop returns missing state identifiers as well as returns filed from Puerto Rico, Guam, or the Virgin Islands.

These restrictions result in a sample of 99,122 joint returns of married couples and 245,321 returns with some other filing status. Weighted descriptive statistics for this sample are shown in Table 2. Dollar amounts are in real 1998 terms. The first column describes the sample as a whole. The next three columns group this sample on the basis of wage income. These three groups are meant to approximate the three regions of the EITC. One problem with this approach is that wage income is likely endogenous to tax parameters, and in my empirical analysis I investigate the robustness of my results to alternative divisions of the sample. The final three columns describe returns with at least one exemption for a dependent child, the treatment group in the following analysis.

For the sample as a whole, approximately $19 \%$ of unmarried returns and $30 \%$ of married returns claim the EITC. These percentages are low because the real income cutoff for the sample, $\$ 30095$, is above the EITC-eligible income in all years of the sample except the last. Rates of EITC receipt appear low also because childless filers are included in the sample. Among returns with a dependent exemption for a child living at home, $82 \%$ of the sample of unmarried filers and $65 \%$ of the sample of married filers claim the EITC.

Taxpayers use Schedule C to report profit or loss from a business organized as a sole proprietorship. Among returns in my sample filed by unmarried filers, 5.7\% report non-zero Schedule

\footnotetext{
${ }^{17}$ Late returns are substantially more likely to report self-employment income. Looking at returns filed up to three years late and satisfying all the other restrictions used to create my sample, $20.2 \%$ of unmarried returns and $43.5 \%$ of joint returns report non-zero self-employment income. Late returns also have a high propensity to claim the EITC. In the same sample of late returns, $21.2 \%$ of unmarried returns and $38.9 \%$ of married returns claim the EITC. This is surprising given the evidence in Slemrod et al. (1997) that those receiving refunds tend to file earlier than those who have a balance due and the evidence in Barrow and McGranahan (2000) that EITC refunds peak earlier in the tax year than do other income tax refunds.

${ }^{18}$ For tax years 1984 to 1988 , only returns with a filing status of married filing jointly or head of household could claim the EITC. Eligibility was expanded to those with a filing status of qualifying widower with dependents in 1989, and additionally to single filers in 1991.
} 
$\mathrm{C}$ income. Among joint returns of married couples this figure is $21.2 \%$. The figure is higher for joint returns in part because the data indicate whether any member of the filing unit earned selfemployment income, and on average those filing jointly live in larger households. Although the tax return itself does specify which individual earned any Schedule C income, this information is not available in the public use dataset. The presence of Schedule $\mathrm{C}$ is not a perfect measure of what is typically thought of as self-employment. In one sense, it is too broad. It includes as self-employed people who may be "moonlighters," with very small amounts of self-employment income. This appears to be the exception for the self-employed EITC recipients in my sample. The mean amount of Schedule C income for these filers is greater than $\$ 5000$, and on average Schedule C income accounts for $41 \%$ of AGI for unmarried filers and $61 \%$ of AGI for married filers. In other contexts, the presence of Schedule $\mathrm{C}$ as an indicator of self-employment has been criticized as too narrow. It ignores income from other types of entrepreneurial activities, such as partnership income, rents and royalties. I exclude these sources from my measure of self-employment because they are not considered earned income for purposes of the EITC.

Ideally, I would like to compare the reporting of self-employment income by filing units with and without EITC qualifying children. Unfortunately the tax return does not report the number of EITC qualifying children. The most similar item available is the number of dependent exemptions claimed for children living at home. The criteria for an EITC qualifying child are slightly different from the criteria for a dependent. ${ }^{19}$ The residency test that must be satisfied by an EITC-qualifying child mandates that a child live with the taxpayer for more than half of the year. The dependent exemption definition waives this requirement for certain children. Conveniently, though, taxpayers must report separately the number of dependent exemptions claimed for children living at home and for children living away from home. In my analysis I classify a return as having EITC qualifying children if there are any dependent exemptions for children at home. This method is not perfect. For example, the dependent

\footnotetext{
${ }^{19}$ Holtzblatt and McCubbin (2003) provide a detailed comparison of the criteria that must be met to claim a child for each of five child-related provisions: the dependent exemption, head of household filing status, the child tax credit, the child and dependent care tax credit, and the EITC.
} 
exemption criteria include a support test - the taxpayer claiming the exemption must provide more than half of the child's support - while the EITC has no support test. The challenge of identifying those with EITC-qualifying children explains why Figure 1 shows, for years before 1994, slightly different values for all EITC recipients and for EITC recipients with children, even though no EITC was available to individuals without qualifying children. ${ }^{20}$

Some simple descriptive statistics are consistent with the hypothesis that the structure of the EITC affects reported self-employment income. The incentive to report positive selfemployment income is greatest in the phase-in region and least in the phase-out region. Table 2 shows that those with real wage income under $\$ 9000$ are more likely to report positive selfemployment income than are those with real wage income above $\$ 14000$. $7.4 \%$ of unmarried filers in the lowest income category report positive self-employment income, versus $1.8 \%$ in the highest income category. Although not shown in the table, the decline in the reporting of self-employment income is more pronounced when the sample is restricted to EITC recipients. Among unmarried EITC recipients, the share reporting positive self-employment income falls from $13.6 \%$ in the lowest-income category to $1.9 \%$ in the middle category and to $1.2 \%$ in the highest income category.

\section{Results}

Before presenting the main regression results, I demonstrate how the reporting of Schedule C income affects the dollar value of EITC payments. All values are expressed in real 1998 dollars. For each EITC recipient, I impute the value of the credit that would be received based on earnings exclusive of net Schedule $\mathrm{C}$ income (that is, wage and salary income only). I assume that the number of EITC qualifying children is equal to the number of exemptions for children living at home. In the first column of Table 3 I compare the imputed credit without Schedule $\mathrm{C}$ income to the actual credit received. By design these two credit amounts will differ due to

\footnotetext{
${ }^{20}$ In my dataset the share of EITC recipients who have zero exemptions for children living at home is between $3.8 \%$ and $5.5 \%$ in each year from 1984 to 1993.
} 
reported self-employment income. In addition, these credit amounts will differ if the number of EITC qualifying children does not equal the number of exemptions for children at home, or if a filer claimed the additional health insurance credit that was briefly part of the EITC in the early 1990s. As an alternative comparison, I predict the credit amount based on reported earnings including Schedule C. ${ }^{21}$ Comparisons of predicted credit amounts with and without Schedule C income are shown in the second column of Table 3. The only source of difference between these two amounts is reported self-employment income. Looking across all EITC recipients, both columns show that reported self-employment income has little effect on the credit received for the majority. Restricting attention to EITC recipients with Schedule C income, however, shows that a large majority of these filers benefit from reporting their self-employment income. About $70 \%$ see their credit increase by $\$ 10$ or more due to their reported self-employment income. Among all EITC recipients with Schedule C income, the mean credit change from reporting self-employment income is an increase of approximately $\$ 650$. The median change is an increase of just over $\$ 300$. These increases are substantial relative to the average real EITC payment of $\$ 1075$. Both the share enjoying a gain and the average amount of additional credit due to reported Schedule $\mathrm{C}$ income are virtually identical across filers who do and do not use a paid preparer.

Table 4 shows the results of estimating the difference-in-difference equation for a sample of low-income, unmarried tax filers. The dependent variable is a dummy equal to 1 if the tax return shows positive Schedule C income. Marginal effects from probit regressions, evaluated at the mean, are shown in the table, with standard errors in parentheses. All regressions use weights provided by the IRS. The first column includes returns with real wage income less than $\$ 9000$. The second column includes returns with real wage income between $\$ 9000$ and $\$ 14000$, while the third column includes returns with real wage income between $\$ 14000$ and $\$ 30095$. The columns can be thought of as roughly corresponding to the three regions of the EITC.

\footnotetext{
${ }^{21}$ In most cases there is little difference between the predicted and actual credit amounts. On average, the actual credit is $\$ 12$ greater than the predicted credit. The prediction method is least accurate in 1991-1993, when a larger credit could be claimed by those who paid for health insurance covering a qualifying child. Over these three years, the actual credit is $\$ 89$ larger than the predicted credit on average.
} 
The coefficients of greatest interest in this table are the three interaction terms. Each of these shows the difference in the growth of self-employment across filers with and without children, all relative to the base period of 1984-86. Consistent with the incentives generated by the EITC, there is some evidence that EITC expansions increase the reporting of self-employment income in the phase-in region and reduce it in the phase-out region. For filers in the lowest income category, there is no evidence that the 1987 or 1991 EITC expansions caused the reporting of self-employment to evolve differently among those with and without children. However, the 1994 expansion is associated with a 3.2 percentage point increase in the reporting of positive Schedule $\mathrm{C}$ income among those with children relative to those without children. This value is significant economically as well as statistically. Averaging over all years of my sample, only $7.4 \%$ of unmarried filers with wage income under $\$ 9000$ report positive self-employment income, so an increase of 3.2 percentage points represents a $43 \%$ change. For filers in the middle income category, self-employment rates evolve similarly for those with and without children. For filers in the highest income category, each of the EITC expansions is associated with a significant reduction in the reporting of self-employment income, relative to the base period. In each case, the reduction is less than 1 percentage point in magnitude.

Many of the other variables included in Table 4 have sensible effects on the reporting of Schedule C income. The coefficients on the three period variables are highly significant, and indicate that the share of unmarried returns reporting self-employment income is generally rising over time. No clear pattern emerges in the relationship between unemployment and self-employment. The hypothesis that a high unemployment rate pushes people into selfemployment receives support in the lowest wage category, but in the mid-wage category higher unemployment rates are associated with lower self-employment rates. The two variables related to state welfare policies should be most relevant for the lowest-income filers, but in fact have little explanatory power for any of the three groups. The presence of a work requirement as part of a pre-1996 welfare waiver has no significant effect on self-employment. Surprisingly, allowing self-employment to satisfy a work requirement after the 1996 reform is associated with 
lower self-employment rates for those in the lowest income category.

A filer who can be claimed as a dependent is ineligible for the EITC. Dependent status is not available in the first three years of my data. In subsequent years, dependents account for about one-third of the low-wage unmarried sample, $8 \%$ of the mid-wage unmarried sample, and $1 \%$ of the high-wage unmarried sample. As a robustness check, I exclude the first three years of data and restrict my sample to non-dependent filers. I again estimate difference-in-difference equations, treating the 1987-1990 period as the baseline. The pattern of results is similar to that seen in Table 4. There is no evidence that the 1991 EITC expansion caused the reporting of self-employment income to evolve differently among those with and without children. For those with wage income less than $\$ 9000$, the 1994 expansion is associated with a significant 4.3 percentage point increase in the reporting of self-employment income among those with children relative to those without.

Results for joint returns of married couples are shown in Table 5. I drop the two variables related to state welfare policies, because very few married couples are eligible for AFDC or TANF. Otherwise, the specification is the same as that used for unmarried filers. As was the case for unmarried filers, there is evidence of a substantial response to the most recent EITC expansion. Among those with real wage income less than $\$ 9000$, the 1994 expansion is associated with a significant 4.1 percentage point increase in the probability of reporting positive Schedule $\mathrm{C}$ income. None of the EITC expansions are associated with significant changes in the reporting of self-employment income among those in the mid- or high-income groups.

A comparison of tables 4 and 5 shows that state unemployment rates and the presence of children affect the reporting of self-employment income differently for married and unmarried filers. For married filers the unemployment rate is consistently negatively correlated with selfemployment. This lends support to the "pull" hypothesis that self-employment is a more attractive option in a stronger economy. Among married filers there is more evidence that the presence of children is associated with a higher probability of reporting self-employment income. This is consistent with the work of Broussard et al. (2006) who suggest that the self-employed 
have more children with the hopes of passing the family business down to the next generation.

In two robustness checks, I augment the basic difference-in-difference equation with a set of state dummies and with state-specific time trends. Neither one of these modifications changes the pattern of coefficients on the interaction terms. The observed self-employment reporting decisions are again broadly consistent with incentives. Both unmarried and married filers with the lowest levels of wage income responded to the 1994 EITC expansion with significant increases in the probability of reporting self-employment income. For unmarried filers, the magnitude of this effect is about 3 percentage points. For married filers, the point estimate is as large as 6 percentage points when state fixed effects are included. Among unmarried filers with real wage income between $\$ 14000$ and $\$ 30095$ there is evidence of significant but small (0.5 to 0.8 percentage point) declines in the reporting of positive self-employment income after each of the EITC expansions.

Like the rest of the tax code, the EITC provisions are complex. The typical taxpayer may not have a complete or accurate understanding of how the EITC affects the tax implications of reporting self-employment income. Paid preparers, however, should fully understand the incentives generated by the EITC. I expect the pattern of increased reported self-employment in the lowest-income group and reduced reported self-employment in the highest-income group to be more pronounced among filers who use a paid preparer. I have estimated Equation 1 separately for those who do and do not use a paid preparer. Information on paid preparer use is missing from the 1985, 1989, and 1990 tax files, and so I drop these three years in this analysis. $^{22}$ The coefficients from the key interaction terms are shown in Table 6 . The results are mixed. Among both unmarried and married filers, the predicted increase in reported selfemployment within the lowest-wage group is driven entirely by filers who do not use a paid preparer. In interpreting these results, it is important to remember that the use of a paid preparer is an endogenous choice made by the taxpayer. Perhaps taxpayers who intend to overstate their self-employment income avoid going to a paid preparer. The predicted decrease

\footnotetext{
${ }^{22}$ Excluding these three years and estimating the regressions for filers pooled together regardless of paid preparer use generates results that are very similar to Tables 4 and 5 .
} 
in reported self-employment within the highest-income group is evident among unmarried filers who use a paid preparer. Overall, Table 6 does not show compelling evidence that paid preparers are advising their clients to report self-employment income in such a way as to maximize the amount of credit received. This is consistent with the finding of Chetty and Saez (2009) that about half of the paid preparers in a large-scale field experiment at H\&R Block encouraged EITC recipients to work more regardless of the EITC region into which they fell.

In a set of regressions not shown, I change the dependent variable to an indicator for reporting negative Schedule C income. The structure of the EITC suggests that credit expansions should reduce the reporting of negative self-employment income in the phase-in region and increase this reporting in the phase-out region. The regression results show that the reporting of negative Schedule C income is largely insensitive to EITC expansions. Most of the interaction terms are insignificant and very close to zero. There is some evidence that married filers with the lowest levels of wage income responded to the two more recent expansions with a reduction in the likelihood of reporting negative self-employment income. The 1991 expansion is associated with a 0.8 percentage point decline and the 1994 expansion with a 1.2 percentage point decline in the probability of reporting negative Schedule $\mathrm{C}$ income, both significant at the $5 \%$ level.

Table 7 shows the results of linear regressions in which the dependent variable is the real dollar amount of net self-employment income reported on Schedule C. These regressions are estimated for the full sample, so the dependent variable can take on positive, zero, and negative values. These regressions show that the most recent EITC expansion is associated with an increase in the dollar amount of Schedule $\mathrm{C}$ income reported by taxpayers with the lowest wage income. For unmarried filers with real wage income less than $\$ 9000$, the 1994 expansion is associated with a significant $\$ 456$ increase in self-employment income among filers with children relative to childless filers. For married filers, the 1986 expansion is associated with a significant $\$ 585$ increase in reported self-employment income and the 1994 expansion is associated with a significant $\$ 1789$ increase in reported self-employment income. As predicted, there is no 
significant effect of EITC expansions on the amount of Schedule C income reported by those with wage income between $\$ 9000$ and $\$ 14000$. The predicted negative effect for those in the highest income category is evident only for unmarried filers after the 1986 expansion, and for this group the magnitude of the coefficient is quite small. In the second panel of Table 7 I restrict the sample to returns reporting positive Schedule $\mathrm{C}$ income. For unmarried filers, none of the coefficients is statistically different from zero. This suggests that the effect of the EITC on reported Schedule C income is concentrated on the extensive margin (the decision to report any Schedule $\mathrm{C}$ income) rather than on the intensive margin. For the lowest-income married filers, there is evidence that the 1994 EITC expansion was associated with an increase in reported Schedule $\mathrm{C}$ income on the intensive margin.

Another way to investigate the sensitivity of reported self-employment income to tax incentives is to compare the dollar amount of net Schedule C income actually reported to the dollar amount that would maximize a filer's EITC. The credit-maximizing amount of self-employment income is the amount that would move a taxpayer to the nearest kink in the EITC schedule. It is positive for taxpayers with wage income within the phase-in region of the EITC and negative for those with wage income in the phase-out region of the EITC. Evidence from my sample suggests a strong correlation between actual and credit-maximizing self-employment amounts. Among all self-employed taxpayers in my sample, the correlation between the credit-maximizing amount of self-employment income and the actual amount of self-employment income is 0.30. Among EITC recipients in my sample, this correlation is 0.51. A regression of actual selfemployment income on the credit-maximizing amount and a constant, for EITC recipients, yields a highly significant coefficient of 0.69 .

Beginning in 1991, the EITC phase-in rate and phase-out rate have been set at higher levels for filers with multiple children than for filers with one child. As a robustness check, I restrict my sample to filers with at least one child, construct a new treatment group made up of those with more than one child, and estimate difference-in-difference equations of the same form as used previously. There should be no significant difference between those with one and with 
multiple children in response to the 1986 expansion, as the law had yet to distinguish between the two groups. If Schedule C reporting decisions are sensitive to EITC parameters, filers with multiple children should demonstrate larger reactions in response to the 1991 and 1994 expansions. This pattern is evident for married filers. Among those with wage income under $\$ 9000$, the probability of reporting positive Schedule C income increased by 7.9 percentage points more for filers with multiple children in response to the 1991 expansion and by 5.3 percentage points more in response to the 1994 expansion. While these coefficients are large, the share of low-wage married filers with kids who report positive Schedule C income is also quite large. Averaged over the entire sample period, this share is 44.9\%. Regressions in which the dependent variable is the real dollar amount of net Schedule $\mathrm{C}$ income also show larger responses of married filers with multiple children to the 1991 and 1994 expansions, but not to the 1986 expansion. For unmarried filers, the responses to EITC expansions never differ between those with one and those with multiple children. This may be partially due to small sample sizes. While $27 \%$ of the married filers in my sample have more than one child, only $8 \%$ of unmarried filers have multiple children. ${ }^{23}$

Results from an alternative specification that does not depend on a comparison of filers with and without children are shown in Table 8. Here, the sample is restricted to filers with at least one child and the incentive to report self-employment income is measured by the phase-in rate. Variation in the phase-in rate comes from federal expansions, from differing treatment of those with different numbers of children, and from state-level EITC programs. The top panel of the table reports marginal effects from probit regressions in which the dependent variable is a dummy equal to one for filers who report positive Schedule C income. For both unmarried and married filers in the lowest income category, an increase in the phase-in rate is associated with an increase in the probability of reporting positive self-employment income. A 10-point increase

\footnotetext{
${ }^{23}$ There is never any difference in the federal EITC parameters facing a filer with two children and a filer with more than two children. As a placebo test, I restrict my sample to filers with two or more children, construct a treatment group consisting of those with at least three children, and again estimate difference-in-difference equations. There is no evidence that filers with two children and filers with more than two children respond differently to EITC expansions.
} 
in the phase-in rate, say from $15 \%$ to $25 \%$, increases the probability of positive self-employment income by 1.6 percentage points among unmarried filers and by 4.1 percentage points among married filers. Between 1986 and 1996, the phase-in rate for a filer with one child increased by 23 percentage points, from $11 \%$ to $34 \%$. The implied increase in the self-employment rate is 3.7 percentage points for unmarried filers and 9.4 percentage points for married filers. While these effects are large, they roughly match the trends shown in Figure 1. The second, third, fifth, and sixth columns of Table 8 consider filers earning too much to be in the phase-in region of the EITC. As expected, changes in the phase-in rate have no significant effect on the reporting of self-employment income among these filers. The bottom panel of Table 8 reports marginal effects from regressions in which the dependent variable is the real dollar amount of net Schedule $\mathrm{C}$ income. These regressions show that both unmarried and married filers in the lowest wage category respond to an increase in the phase-in rate by reporting more selfemployment income. A 10-point increase in the phase-in rate is associated with an additional $\$ 152$ of reported Schedule C income among unmarried filers and an additional $\$ 851$ of reported Schedule C income among married filers.

I have chosen to divide the sample into three groups, based on real wage income, that approximate the three regions of the EITC. One problem with this approach is that wage income is endogenous. Other studies have identified groups likely to be affected by the EITC on the basis of more plausibly exogenous characteristics, such as education, as in Eissa and Liebman (1996), and predicted wage, as in Ellwood (2000). A second problem is that the cutoffs I use, $\$ 9000$ and $\$ 14000$, do not perfectly align with the cutoffs between the three regions of the EITC. The use of tax return data prevents me from defining groups on the basis of demographic information. I can, however, check the sensitivity of my results to alternative income-based definitions of the three groups. I consider three alternatives. First, I replace $\$ 9000$ and $\$ 14000$ with the most generous EITC cutoffs in place during a given year. That is, I use the EITC cutoffs for filers with qualifying children prior to 1994 and the cutoffs for filers with two or more children beginning in 1994. Second, I use the EITC cutoffs that applied to a 
filer with one qualifying child in each year. Third, I return to the cutoffs of $\$ 9000$ and $\$ 14000$, but group returns on the basis of AGI rather than wage income. The results for unmarried filers are robust to these changes. Within the lowest income group, however it is defined, the 1994 EITC expansion is associated with a significantly greater increase in the reporting of self-employment income for unmarried filers with children relative to childless filers. The magnitude of this difference-in-difference coefficient varies from 2.1 percentage points to 4.4 percentage points. The results for married filers are less consistent across specifications. When returns are grouped on the basis of AGI, none of the EITC expansions is associated with a significant change in the reporting of self-employment income within the lowest-income group. Within the middle income category, where the plateau shape of the EITC should have little effect on reported self-employment, the most recent expansion is associated with a significant and large increase in reported self-employment. Within the highest income category, all three expansions are associated with significant increases in reported self-employment, even though the EITC expansions increased the tax cost of reporting self-employment income for those in the phase-out region.

\section{Conclusion}

The EITC subsidizes earnings of low-income individuals, treating earnings from wage work and earnings from self-employment in the same way. The literature estimating the labor supply effects of the credit has largely focused on the wage sector, and has found substantial increases in the labor force participation rate of single mothers in response to EITC expansions. In this paper I use tax return data from 1984 to 1998 to investigate how EITC expansions have influenced the reporting of self-employment income to the IRS.

I use a difference-in-difference strategy similar to what has previously been used in the EITC literature. I compare changes in the reporting of self-employment income across filers with and without children. Those with children face larger changes in the incentive to report self- 
employment income as a result of EITC expansions. I find that the most recent EITC expansion, effective in 1994, is associated with a significant increase in the reporting of positive selfemployment income by the lowest-income filers. Relative to tax years 1984-1986, the probability of reporting positive self-employment income increases by 3.2 percentage points more among unmarried filers with children than among unmarried filers without children. For married filers, the corresponding increase is 4.1 percentage points. This behavior is consistent with the increase in the effective subsidy these taxpayers faced for reporting additional earnings. In an alternative strategy that does not rely on comparing filers with and without children, I find that increases in the phase-in rate are associated with increased reporting of self-employment income among both married and unmarried taxpayers with the lowest levels of income.

Using unaudited tax return data makes it difficult to draw any conclusions about how EITC expansions affect the accuracy of reported self-employment income. The increased reporting of self-employment income that I find for the lowest-income filers could correspond to improved compliance, if taxpayers have begun to report some income that previously would have gone unreported. If reported and actual self-employment income have increased together, compliance is unchanged. Finally, compliance may have worsened if individuals have begun to report more self-employment income than they have actually earned. Steuerle (1991) has dubbed this scenario the "superterranean economy." A comparison of the reporting patterns present in tax return data to patterns of self-employment activity present in survey data might shed light on the compliance question. I leave this avenue open for future research.

\section{References}

Allingham, Michael G. and Agnar Sandmo. 1972. "Income Tax Evasion: A Theoretical Analysis." Journal of Public Economics 1(3): 323-338.

Barrow, Lisa and Leslie McGranahan. 2000. "The Effects of the Earned Income Credit on the Seasonality of Household Expenditure." National Tax Journal 53(4, part 2): 1211-1243.

Baughman, Reagan and Stacy Dickert-Conlin. 2003. "Did Expanding the EITC Promote Motherhood?" American Economic Review, Papers and Proceedings 93(2): 247-251. 
Baughman, Reagan and Stacy Dickert-Conlin. Forthcoming. "The Earned Income Tax Credit and Fertility." Journal of Population Economics.

Blau, David M. 1987. "A Time-Series Analysis of Self-Employment in the United States." Journal of Political Economy 95(3): 445-467.

Broussard, Nzinga, Ralph Chami and Gregory D. Hess. 2006. "(Why) Do SelfEmployed Parents Have More Children?" Working paper.

Bruce, Donald. 2000. "Effects of the United States Tax System on Transitions into Self-Employment." Labour Economics 7(5): 547-575.

Bruce, Donald. 2002. "Taxes and Entrepreneurial Endurance: Evidence from the Self-Employed." National Tax Journal 55(1): 5-24.

Chetty, Raj and Emmanuel Saez. 2009. "Teaching the Tax Code: Earnings Responses to an Experiment with EITC Recipients." NBER Working Paper No. 14836.

Congressional Budget Office. 2003. Effective Federal Tax Rates, 1997 to 2000. Washington: Government Printing Office.

Cullen, Julie Berry and Roger Gordon. 2006. "Tax Reform and Entrepreneurial Activity." Tax Policy and the Economy 20: 41-71.

Dickert-Conlin, Stacy, Scott Houser, and John Karl Scholz. 1995. "The Earned Income Tax Credit and Transfer Programs: A Study of Labor Market and Program Participation." Tax Policy and the Economy 9: 1-50.

Domar, Evsey D. and Richard A. Musgrave. 1944. "Proportional Income Taxation and Risk-Taking." Quarterly Journal of Economics. 58(3): 388-422.

Edin, Kathryn and Laura Lein. 1997. Making Ends Meet: How Single Mothers Survive Welfare and Low-Wage Work. New York: Russell Sage.

Eissa, Nada and Jeffrey B. Liebman. 1996. "Labor Supply Response to the Earned Income Tax Credit." Quarterly Journal of Economics 111(2): 605-637.

Eissa, Nada and Hilary Williamson Hoynes. 2004. "Taxes and the Labor Market Participation of Married Couples: The Earned Income Tax Credit." Journal of Public Economics 88(9-10): 1931-1958.

Ellwood, David T. 2000. "The Impact of the Earned Income Tax Credit and Social Policy Reforms on Work, Marriage, and Living Arrangements." National Tax Journal 53(4, part 2): 1063-1106. 
Fairlie, Robert W. and Bruce D. Meyer. 2000. "Trends in Self-Employment among White and Black Men During the Twentieth Century." Journal of Human Resources 35(4): 643-669.

Feenberg, Daniel and Elisabeth Coutts. 1993. "An Introduction to the TAXSIM Model." Journal of Policy Analysis and Management 12(1): 1889-194.

Feldstein, Martin and Andrew Samwick. 1992. "Social Security Rules and Marginal Tax Rates." National Tax Journal 45(1): 1-22.

Gentry, William M. and R. Glenn Hubbard. 2000. "Tax Policy and Entrepreneurial Entry." American Economic Review 90(2): 283-287.

Gurley-Calvez, Tami and Donald Bruce. 2008. "Do Tax Cuts Promote Entrepreneurial Longevity?" National Tax Jouranl 61(2): 225-250.

Hill, Carolyn J., V. Joseph Hotz, Charles H. Mullin, and John Karl Scholz. 1999. "EITC Eligibility, Participation, and Compliance Rates for AFDC Households: Evidence from the California Caseload." Report to the U.S. Department of Health and Human Services, California Department of Social Services and California Franchise Tax Board.

Holtzblatt, Janet and Janet McCubbin. 2003. "Whose Child Is It Anyway? Simplifying the Definition of a Child." National Tax Journal 56(3): 701-718.

Hotz, V. Joseph and John Karl Scholz. 2003. "The Earned Income Tax Credit." In Means-Tested Transfer Programs in the United States, ed. R. Moffitt, 141-197. University of Chicago Press and NBER.

Internal Revenue Service. 2006. IRS Updates Tax Gap Estimates. IRS Press Release IR-2006-28.

Joulfaian, David and Mark Rider. 1996. "Tax Evasion in the Presence of Negative Income Tax Rates." National Tax Journal. 49(4): 553-572.

Kesselman, Jonathan R. 1989. "Income Tax Evasion: An Intersectoral Analysis." Journal of Public Economics 38(2): 137-182.

Liebman, Jeffrey B. 2000. "Who Are the Ineligible EITC Recipients?" National Tax Journal 53(4, part 2): 1165-1186.

Long, James E. 1982. "The Income Tax and Self-Employment." National Tax Journal 35(1): 31-42.

Meyer, Bruce D. and Dan T. Rosenbaum. 2001. "Welfare, the Earned Income Tax Credit, and the Labor Supply of Single Mothers." Quarterly Journal of Economics 117(3): 1063-1114. 
Moore, Robert L. 1983. "Self-employment and the Incidence of the Payroll Tax." National Tax Journal 36(4): 491-501.

Moore, Kevin. 2004. "The Effects of the 1986 and 1993 Tax Reforms on SelfEmployment." Finance and Economics Discussion Series 2004-05, Board of Governors of the Federal Reserve System.

Pestieau, Pierre and Uri M. Possen. 1991. "Tax Evasion and Occupational Choice." Journal of Public Economics 45(1): 107-125.

Parker, Simon C. 2004. The Economics of Self-Employment and Entrepreneurship. Cambridge: Cambridge University Press.

Schuetze, Herbert J. and Donald Bruce. 2004. "Tax Policy and Entrepreneurship." Swedish Economic Policy Review 11(2): 233-265.

Slemrod, Joel. 1990. "The Economic Impact of Tax Reform." In Do Taxes Matter? The Impact of the Tax Reform Act of 1986, ed. Joel Slemrod, 1-12. Cambridge: MIT Press.

Slemrod, Joel, Charles Christian, Rebecca London, and Jonathan Parker. 1997. "April 15 Syndrome." Economic Inquiry 35(4): 695-709.

Steuerle, Gene. 1991. "The Superterranean Economy." Tax Notes May 6: 647.

Venkatesh, Sudhir. 2006. Off the Books: The Underground Economy of the Urban Poor. Cambridge: Harvard University Press.

Yitzhaki, Shlomo. 1974. "A Note on Income Tax Evasion: A Theoretical Analysis." Journal of Public Economics. 3(2): 201-202. 
Table 1: EITC Parameters in Four Time Periods

\begin{tabular}{lcccc}
\hline \hline & Period 1 & Period 2 & Period 3 & Period 4 \\
& $1984-86$ & $1987-90$ & $1991-93$ & $1994-98$ \\
\cline { 2 - 5 } Average Number of Recipient Households (1000s) & 6988 & 11031 & 14293 & 19496 \\
Maximum Credit, One Child & 812 & 1202 & 1529 & 2249 \\
Maximum Credit, No Children & 0 & 0 & 0 & 338 \\
Maximum Phase-in Rate, One Child (Percent) & 11 & 14 & 18.5 & 34 \\
Maximum Phase-out Rate, One Child (Percent) & 12.5 & 10 & 13.21 & 15.98 \\
\hline \hline
\end{tabular}

Note: Data on the number of recipients are from the Internal Revenue Service, Statistics of Income Division. Data on EITC parameters are from the Green Book of the House Ways and Means Committee. Maximum credit amounts are expressed in real 1998 dollars. 


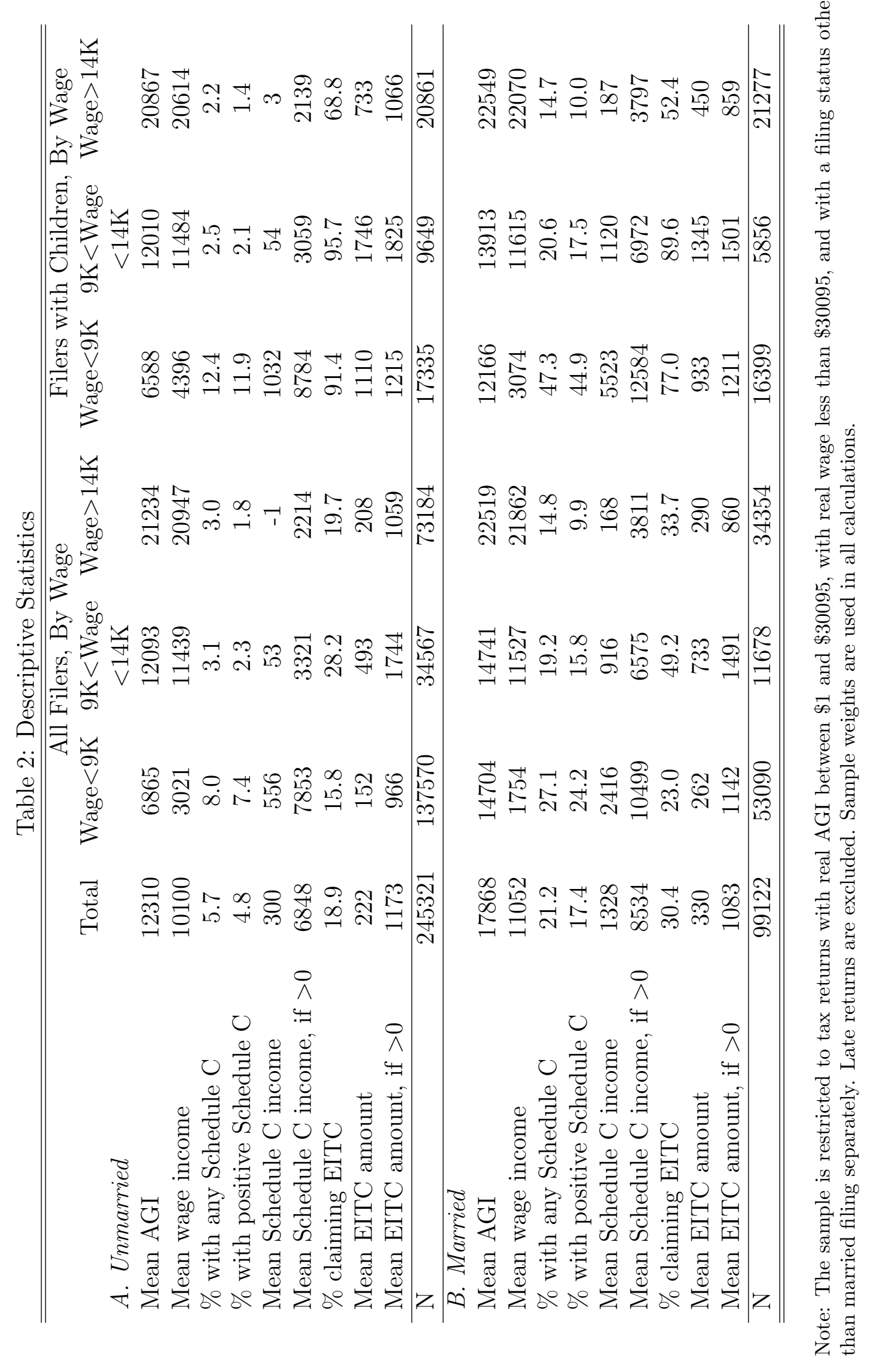


Table 3: Changes in Credit Amount Due to Reported Schedule C Income

\begin{tabular}{lcc}
\hline \hline & Compared to Actual Credit & Compared to Predicted Credit \\
Share of All EITC Recipients & & \\
$\mid$ Change $\mid<\$ 10$ & 66.8 & 87.5 \\
Increase $\geq \$ 10$ & 18.2 & 9.3 \\
Decrease $\geq \$ 10$ & 15.0 & 3.2 \\
Share of EITC Recipients with Schedule C Income & 5.9 \\
$\quad \mid$ Change $\mid<\$ 10$ & 3.0 & 69.9 \\
Increase $\geq \$ 10$ & 70.5 & 24.3 \\
Decrease $\geq \$ 10$ & 26.5 & \\
Mean Dollar Change in Credit & & 656 \\
$\quad$ All Recipients with Schedule C & 640 & 1102 \\
Gainers & 1111 & -472 \\
Losers & -540 & 310 \\
Median Dollar Change in Credit & & 748 \\
All Recipients with Schedule C & 324 & -292 \\
Gainers & 766 & \\
Losers & -351 & \\
\hline \hline
\end{tabular}

Note: The actual credit amount is equal to the sum of three variables in the SOI data: the credit used to offset income tax, the credit used to offset any other tax liability, and the refundable portion of the credit. The predicted credit is calculated by applying the relevant EITC parameters to the EITC income reported in the SOI data. All amounts are expressed in real 1998 dollars. 
Table 4: Reporting of Positive Schedule C Income, Unmarried Filers

\begin{tabular}{lccl}
\hline \hline & Wage $<9 \mathrm{~K}$ & $9 \mathrm{~K}<$ Wage $<14 \mathrm{~K}$ & $14 \mathrm{~K}<$ Wage $<30 \mathrm{~K}$ \\
Kids & $0.034^{* * *}$ & -0.002 & 0.0003 \\
& $(0.006)$ & $(0.004)$ & $(0.002)$ \\
Period2 & $0.008^{* * *}$ & 0.004 & $0.005^{* * *}$ \\
$\quad(1987-1990)$ & $(0.002)$ & $(0.003)$ & $(0.002)$ \\
Interact2 & -0.003 & 0.0002 & $-0.008^{* * *}$ \\
& $(0.006)$ & $(0.006)$ & $(0.002)$ \\
Period3 & $0.018^{* * *}$ & $0.012^{* * *}$ & $0.010^{* * *}$ \\
$\quad(1991-1993)$ & $(0.002)$ & $(0.003)$ & $(0.002)$ \\
Interact3 & -0.006 & -0.004 & $-0.008^{* * *}$ \\
& $(0.006)$ & $(0.005)$ & $(0.002)$ \\
Period4 & $0.026^{* * *}$ & $0.007^{* * *}$ & $0.009^{* * *}$ \\
$\quad(1994-1996)$ & $(0.002)$ & $(0.003)$ & $(0.002)$ \\
Interact4 & $0.032^{* * *}$ & -0.0001 & $-0.005^{* *}$ \\
& $(0.007)$ & $(0.005)$ & $(0.002)$ \\
Unemp Rate & $0.002^{* * *}$ & $-0.001^{* *}$ & -0.00005 \\
& $(0.0004)$ & $(0.0005)$ & $(0.0003)$ \\
Work Requirement, Pre-96 & -0.002 & 0.001 & -0.002 \\
& $(0.003)$ & $(0.003)$ & $(0.002)$ \\
SE Satisfies Work Req, Post-96 & $-0.009^{* * *}$ & 0.001 & 0.004 \\
& $(0.002)$ & $(0.003)$ & $(0.003)$ \\
\hline $\mathrm{N}$ & 137570 & 34567 & 73184 \\
\hline \hline
\end{tabular}

Note: The dependent variable is a dummy equal to 1 if positive Schedule $\mathrm{C}$ income is reported. The table reports marginal effects from probit regressions, evaluated at the mean. Standard errors are in parentheses. Sample weights are used in all regressions. 
Table 5: Reporting of Positive Schedule C Income, Married Filers

\begin{tabular}{lccc}
\hline \hline & Wage $<9 \mathrm{~K}$ & $9 \mathrm{~K}<$ Wage $<14 \mathrm{~K}$ & $14 \mathrm{~K}<$ Wage $<30 \mathrm{~K}$ \\
Kids & $0.135^{* * *}$ & $0.041^{* *}$ & 0.001 \\
& $(0.016)$ & $(0.016)$ & $(0.007)$ \\
Period2 & 0.007 & $-0.013^{*}$ & 0.012 \\
$\quad(1987-1990)$ & $(0.015)$ & $(0.016)$ & $(0.008)$ \\
Interact2 & 0.007 & 0.022 & 0.004 \\
& $(0.020)$ & $(0.022)$ & $(0.010)$ \\
Period3 & $0.043^{* * *}$ & $0.056^{* * *}$ & $0.031^{* * *}$ \\
$\quad(1991-1993)$ & $(0.015)$ & $(0.017)$ & $(0.009)$ \\
Interact3 & -0.029 & -0.030 & -0.005 \\
& $(0.019)$ & $(0.019)$ & $(0.010)$ \\
Period4 & 0.011 & 0.019 & $0.027^{* * *}$ \\
$(1994-1996)$ & $(0.014)$ & $(0.015)$ & $(0.008)$ \\
Interact4 & $0.041^{* *}$ & 0.004 & 0.004 \\
& $(0.020)$ & $(0.019)$ & $(0.009)$ \\
Unemp Rate & $-0.013^{* * *}$ & $-0.012^{* * *}$ & $-0.005^{* * *}$ \\
\hline $\mathrm{N}$ & $(0.002)$ & $(0.002)$ & $(0.001)$ \\
\hline \hline
\end{tabular}

Note: The dependent variable is a dummy equal to 1 if positive Schedule $\mathrm{C}$ income is reported. The table reports marginal effects from probit regressions, evaluated at the mean. Standard errors are in parentheses. Sample weights are used in all regressions. 
Table 6: Reporting of Positive Schedule C Income, By Paid Preparer Use

\begin{tabular}{|c|c|c|c|c|c|c|}
\hline \multirow{2}{*}{\multicolumn{2}{|c|}{\begin{tabular}{cc} 
& Unn \\
\cline { 2 - 3 } & Low \\
Wage \\
A. No Paid Preparer
\end{tabular}}} & \multicolumn{2}{|c|}{ married Filers } & \multicolumn{3}{|c|}{ Married Filers } \\
\hline & & $\begin{array}{c}\text { Mid } \\
\text { Wage }\end{array}$ & $\begin{array}{l}\text { High } \\
\text { Wage }\end{array}$ & $\begin{array}{l}\text { Low } \\
\text { Wage }\end{array}$ & $\begin{array}{l}\text { Mid } \\
\text { Wage }\end{array}$ & $\begin{array}{l}\text { High } \\
\text { Wage }\end{array}$ \\
\hline & $\begin{array}{l}-0.0003 \\
(0.009)\end{array}$ & $\begin{array}{c}0.003 \\
(0.009)\end{array}$ & $\begin{array}{l}-0.004 \\
(0.003)\end{array}$ & $\begin{array}{r}0.019 \\
(0.038\end{array}$ & $\begin{array}{c}0.066 \\
(0.048)\end{array}$ & $\begin{array}{l}-0.012 \\
(0.013)\end{array}$ \\
\hline Interact3 & $\begin{array}{c}0.016^{*} \\
(0.010)\end{array}$ & $\begin{array}{c}0.003 \\
(0.008)\end{array}$ & $\begin{array}{l}-0.006^{* *} \\
(0.002)\end{array}$ & $\begin{array}{c}0.026 \\
(0.034)\end{array}$ & $\begin{array}{l}-0.0007 \\
(0.029)\end{array}$ & $\begin{array}{c}0.001 \\
(0.014)\end{array}$ \\
\hline Interact4 & $\begin{array}{l}0.057^{* * *} \\
(0.014)\end{array}$ & $\begin{array}{c}0.003 \\
(0.008)\end{array}$ & $\begin{array}{l}-0.002 \\
(0.003)\end{array}$ & $\begin{array}{l}0.088^{* * *} \\
(0.037)\end{array}$ & $\begin{array}{c}0.064^{* *} \\
(0.036)\end{array}$ & $\begin{array}{c}0.003 \\
(0.013)\end{array}$ \\
\hline $\mathrm{N}$ & 56821 & 16732 & 35395 & 5633 & 3387 & 11245 \\
\hline \multicolumn{7}{|c|}{ B. Paid Preparer } \\
\hline Interact2 & $\begin{array}{c}0.010 \\
(0.019)\end{array}$ & $\begin{array}{l}-0.006 \\
(0.016)\end{array}$ & $\begin{array}{l}-0.016^{* *} \\
(0.006)\end{array}$ & $\begin{array}{c}0.002 \\
(0.039)\end{array}$ & $\begin{array}{c}0.008 \\
(0.045)\end{array}$ & $\begin{array}{c}0.022 \\
(0.023)\end{array}$ \\
\hline Interact3 & $\begin{array}{l}-0.054^{* * *} \\
(0.011)\end{array}$ & $\begin{array}{l}-0.017 \\
(0.011)\end{array}$ & $\begin{array}{l}-0.015^{* *} \\
(0.005)\end{array}$ & $\begin{array}{l}-0.072^{* *} \\
(0.031)\end{array}$ & $\begin{array}{l}-0.082^{* *} \\
(0.031)\end{array}$ & $\begin{array}{l}-0.015 \\
(0.017)\end{array}$ \\
\hline Interact4 & $\begin{array}{l}-0.022 \\
(0.013)\end{array}$ & $\begin{array}{l}-0.011 \\
(0.012)\end{array}$ & $\begin{array}{l}-0.015^{* *} \\
(0.006)\end{array}$ & $\begin{array}{l}-0.00001 \\
(0.032)\end{array}$ & $\begin{array}{l}-0.065^{*} \\
(0.032)\end{array}$ & $\begin{array}{l}-0.005 \\
(0.017)\end{array}$ \\
\hline $\mathrm{N}$ & 54481 & 10941 & 22459 & 11792 & 6191 & 16114 \\
\hline
\end{tabular}

Note: This table reports a subset of the marginal effects from probit regressions in which the dummy variable is equal to 1 if positive Schedule C income is reported. The full set of regressors used here is the same as the set reported in Tables 4 and 5. Standard errors are in parentheses. Sample weights are used in all regressions. The paid preparer variable is not available for tax years 1985, 1989, and 1990. Observations from these years are dropped from the regressions reported above. 
Table 7: Dollar Amount of Schedule C Income Reported

\begin{tabular}{lccccccc}
\hline \hline & \multicolumn{3}{c}{ Unmarried Filers } & & \multicolumn{3}{c}{ Married Filers } \\
\cline { 2 - 3 } \cline { 7 - 8 } & Low & Mid & High & & Low & Mid & High \\
Wage & Wage & Wage & & Wage & Wage & Wage \\
A. Full Sample & & & & & & \\
Interact2 & -14 & -20 & $-36^{* * *}$ & & $585^{* *}$ & 133 & -42 \\
& $(85)$ & $(22)$ & $(13)$ & & $(239)$ & $(181)$ & $(66)$ \\
Interact3 & 5 & -5 & -17 & & 262 & -36 & 1 \\
& $(84)$ & $(20)$ & $(13)$ & & $(243)$ & $(169)$ & $(67)$ \\
Interact4 & $456^{* * *}$ & 16 & -10 & & $1789^{* * *}$ & 156 & 13 \\
& $(81)$ & $(18)$ & $(12)$ & & $(230)$ & $(161)$ & $(62)$ \\
\hline N & 137570 & 34567 & 73184 & & 53090 & 11678 & 34354 \\
\hline B. Returns & with Positive Schedule C & Income & & \\
Interact2 & 114 & -197 & -267 & & 436 & 174 & -211 \\
& $(678)$ & $(864)$ & $(490)$ & & $(476)$ & $(844)$ & $(438)$ \\
Interact3 & 309 & 613 & -184 & & -118 & 1118 & 257 \\
& $(642)$ & $(825)$ & $(473)$ & & $(483)$ & $(782)$ & $(428)$ \\
Interact4 & 297 & 706 & -196 & & $1073^{* *}$ & 893 & -51 \\
& $(586)$ & $(727)$ & $(429)$ & & $(435)$ & $(743)$ & $(404)$ \\
\hline $\mathrm{N}$ & 18523 & 1571 & 2377 & 18435 & 2884 & 5779 \\
\hline \hline
\end{tabular}

Note: The dependent variable is amount of net Schedule C income reported, in real 1998 dollars. The table reports marginal effects from OLS regressions. Standard errors are in parentheses. Sample weights are used in all regressions. 
Table 8: Using Variation in Phase-In Rate, Filers with Children Only

\begin{tabular}{|c|c|c|c|c|c|c|}
\hline & \multicolumn{3}{|c|}{ Unmarried Filers } & \multicolumn{3}{|c|}{ Married Filers } \\
\hline & Low & Mid & High & Low & Mid & High \\
\hline & Wage & Wage & Wage & Wage & Wage & Wage \\
\hline \multicolumn{7}{|c|}{ A. Dep Var $=1$ if Any Positive Schedule C Income } \\
\hline $\begin{array}{l}\text { Phase-In Rate } \\
\text { (in 10s) }\end{array}$ & $\begin{array}{l}0.016^{* * *} \\
(0.004)\end{array}$ & $\begin{array}{l}-0.002 \\
(0.002)\end{array}$ & $\begin{array}{l}-0.001 \\
(0.001)\end{array}$ & $\begin{array}{l}0.041^{* * *} \\
(0.009)\end{array}$ & $\begin{array}{c}0.006 \\
(0.009)\end{array}$ & $\begin{array}{c}0.004 \\
(0.004)\end{array}$ \\
\hline Time & $\begin{array}{l}0.003^{* * *} \\
(0.001)\end{array}$ & $\begin{array}{l}0.001 \\
(0.0006)\end{array}$ & $\begin{array}{r}0.0006^{*} \\
(0.0004)\end{array}$ & $\begin{array}{l}-0.001 \\
(0.002)\end{array}$ & $\begin{array}{c}0.001 \\
(0.002)\end{array}$ & $\begin{array}{c}0.002 \\
(0.001)\end{array}$ \\
\hline Unemp Rate & $\begin{array}{l}-0.003^{*} \\
(0.0016)\end{array}$ & $\begin{array}{l}-0.001 \\
(0.001)\end{array}$ & $\begin{array}{l}-0.0001 \\
(0.0004)\end{array}$ & $\begin{array}{l}-0.017^{* * *} \\
(0.003)\end{array}$ & $\begin{array}{l}-0.017^{* * *} \\
(0.003)\end{array}$ & $\begin{array}{l}-0.007^{* * *} \\
(0.001)\end{array}$ \\
\hline $\begin{array}{l}\text { Work Requirement, } \\
\text { Pre-96 }\end{array}$ & $\begin{array}{l}-0.012 \\
(0.008)\end{array}$ & $\begin{array}{l}-0.006 \\
(0.004)\end{array}$ & $\begin{array}{l}-0.001 \\
(0.003)\end{array}$ & & & \\
\hline $\begin{array}{l}\text { SE Satisfies Work } \\
\text { Req, Post-96 }\end{array}$ & $\begin{array}{l}-0.0003 \\
(0.011)\end{array}$ & $\begin{array}{l}-0.002 \\
(0.005)\end{array}$ & $\begin{array}{c}0.003 \\
(0.004)\end{array}$ & & & \\
\hline $\mathrm{N}$ & 17335 & 9649 & 20861 & 16399 & 5856 & 21277 \\
\hline \multicolumn{7}{|c|}{ B. Dep Var $=$ Net Schedule C Income } \\
\hline $\begin{array}{l}\text { Phase-In Rate } \\
\text { (in 10s) }\end{array}$ & $\begin{array}{l}151.6^{* * *} \\
(49.7)\end{array}$ & $\begin{array}{c}-0.8 \\
(11.7)\end{array}$ & $\begin{array}{c}1.2 \\
(5.1)\end{array}$ & $\begin{array}{l}851.4^{* * *} \\
(150.6)\end{array}$ & $\begin{array}{l}135.3 \\
(84.2)\end{array}$ & $\begin{array}{l}59.6^{* *} \\
(24.7)\end{array}$ \\
\hline Time & $\begin{array}{c}20.0 \\
(12.6)\end{array}$ & $\begin{array}{c}1.9 \\
(2.8)\end{array}$ & $\begin{array}{l}-0.7 \\
(1.5)\end{array}$ & $\begin{array}{l}-57.8 \\
(38.4)\end{array}$ & $\begin{array}{l}-27.6 \\
(21.6)\end{array}$ & $\begin{array}{r}-10.5 \\
(6.4)\end{array}$ \\
\hline Unemp Rate & $\begin{array}{l}-36.6^{* *} \\
(16.1)\end{array}$ & $\begin{array}{l}5.5^{*} \\
(3.2)\end{array}$ & $\begin{array}{c}0.8 \\
(1.9)\end{array}$ & $\begin{array}{c}-243.1^{* * *} \\
(46.5)\end{array}$ & $\begin{array}{c}-134.0^{* * *} \\
(28.5)\end{array}$ & $\begin{array}{c}-18.7^{* *} \\
(7.3)\end{array}$ \\
\hline $\begin{array}{l}\text { Work Requirement, } \\
\text { Pre-96 }\end{array}$ & $\begin{array}{l}-194.9^{*} \\
(104.1)\end{array}$ & $\begin{array}{c}7.7 \\
(22.3)\end{array}$ & $\begin{array}{c}11.6 \\
(12.8)\end{array}$ & & & \\
\hline $\begin{array}{l}\text { SE Satisfies Work } \\
\text { Req, Post-96 }\end{array}$ & $\begin{array}{c}-34.4 \\
(156.1) \\
\end{array}$ & $\begin{array}{c}48.9 \\
(35.8) \\
\end{array}$ & $\begin{array}{c}-6.7 \\
(16.5) \\
\end{array}$ & & & \\
\hline $\mathrm{N}$ & 17335 & 9649 & 20861 & 16399 & 5856 & 21277 \\
\hline
\end{tabular}

Note: The sample is restricted to returns claiming at least one dependent exemption for a child living at home. The dependent variable is a dummy equal to 1 if positive Schedule $\mathrm{C}$ income is reported. The table reports marginal effects from probit regressions, with standard errors in parentheses. Sample weights are used in all regressions. 
Figure 1: Share of Low-Income Returns with Positive Self-Employment Income

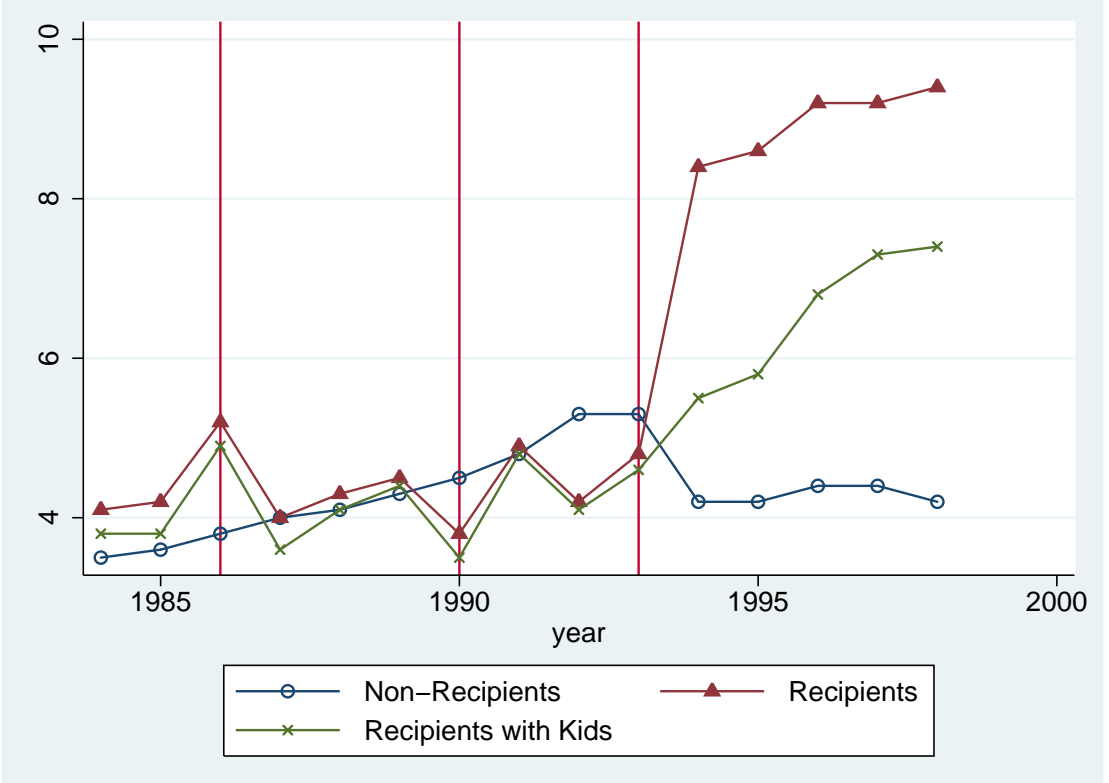

(a) Unmarried

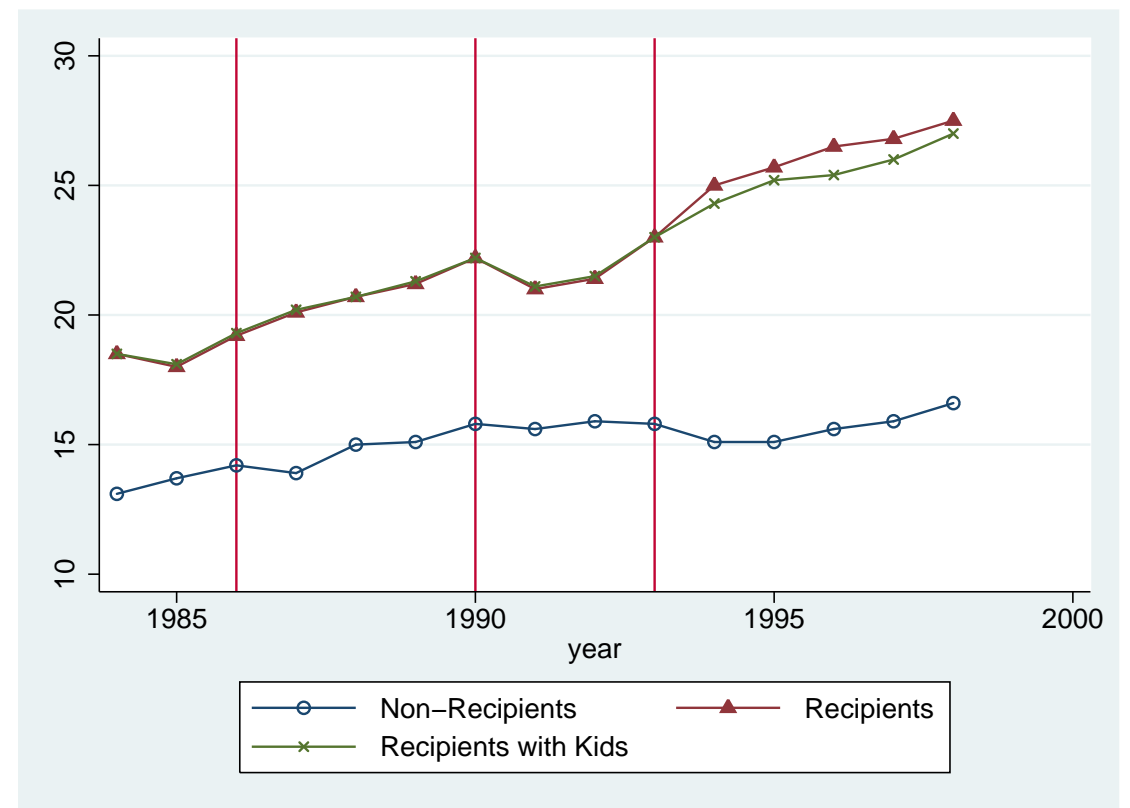

(b) Married

Note: The sample is restricted to tax returns with real AGI between $\$ 1$ and $\$ 30095$, with real wage income less than $\$ 30095$, and with a filing status other than married filing separately. Late returns are excluded. Selfemployment income is defined as Schedule C income. Vertical lines show years in which EITC expansions were passed, and each expansion is effective in the following year. 
Figure 2: Change in Tax Liability from Reporting $\$ 500$ of Self-Employment Income, Difference Between Unmarried Filers with One and Zero Dependents

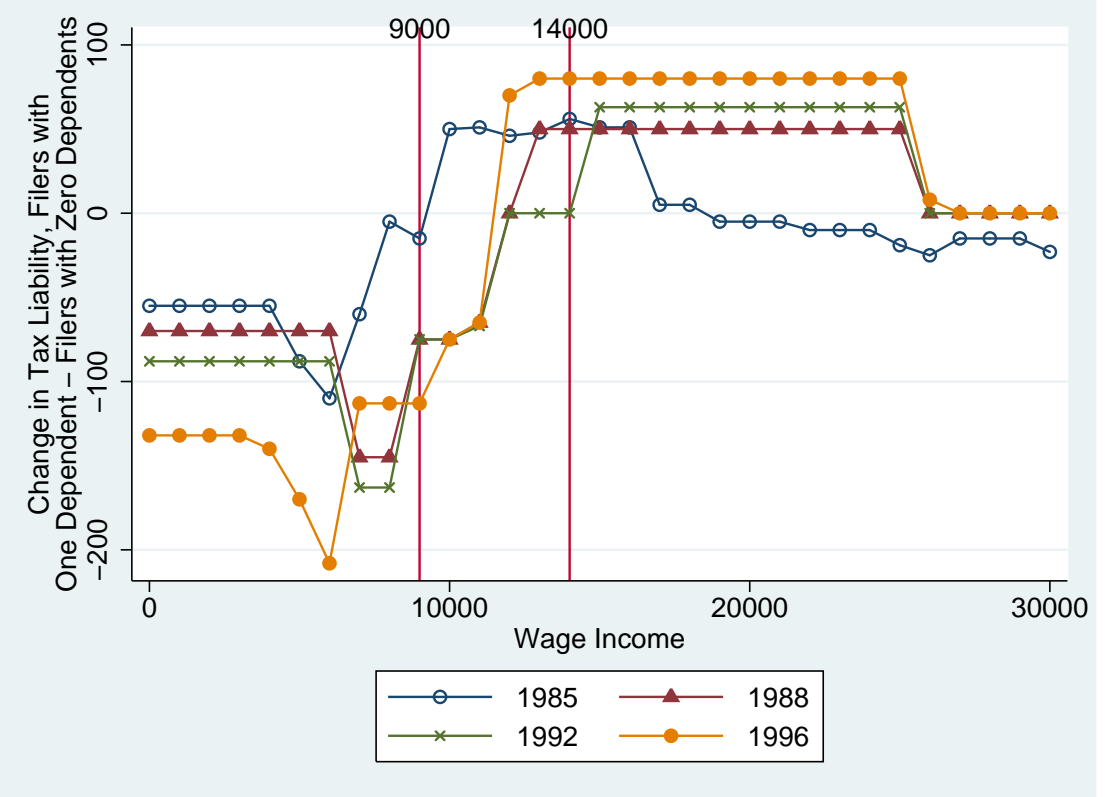

Note: I used TAXSIM to compute how a filer's tax liability would change if she reported $\$ 500$ of real selfemployment income, starting at various levels of wage income. This table shows the difference between the change in tax liability for an unmarried filer with one dependent child and the change in tax liability for an unmarried filer with zero dependents. All dollar amounts are in real 1998 dollars. Negative dollar amounts represent reductions in tax liability (equivalently, increases in refundable credits). 